Bioscientia Medicina: Journal of Biomedicine \& Translational Research

Journal Homepage: www.bioscmed.com

\title{
Congenital Heart Diseases in Pregnancy
}

\section{Nuswil Bernolian ${ }^{1,2 *}$, Radiyati Umi Partan ${ }^{1,3}$, Siti Nurmaini ${ }^{1,4}$, Cindy Kesty ${ }^{2}$, Benedictus Wicaksono Widodo 5}

${ }^{1}$ Biomedicine Doctoral Program, Faculty of Medicine, Universitas Sriwijaya, Palembang, South Sumatera, Indonesia 2Division of Maternal Fetal Medicine, Department of Obstetrics and Gynecology, Mohammad Hoesin General Hospital/Faculty of Medicine, Universitas Sriwijaya, Palembang, South Sumatera, Indonesia

${ }^{3}$ Division of Rheumatology, Department of Internal Medicine, Mohammad Hoesin General Hospital/Faculty of Medicine, Universitas Sriwijaya, Palembang, South Sumatera, Indonesia

${ }^{4}$ Faculty of Computer Science, Universitas Sriwijaya, Palembang, South Sumatera, Indonesia

5Biomedical Science Master Program, Faculty of Medicine, Universitas Sriwijaya, Palembang, South Sumatera, Indonesia

\section{A R T I C L E I N F O \\ Keywords: \\ Congenital heart disease \\ Ultrasonography \\ Pregnancy}

\section{*Corresponding author:}

Nuswil Bernolian

E-mail address:

nuswilbernoli@gmail.com

All authors have reviewed and approved the final version of the manuscript.

https://doi.org/10.32539/bsm.v5i4.376

\begin{abstract}
A B S T R A C T
This research aims to shed light into congenital heart diseases, the pathophysiology, and the ultrasonographic findings of congenital heart diseases. Congenital heart diseases are a major health concern, affecting 1.35 million children born every year. Ventricular septal defect, atrial septal defect, and atrioventricular septal defect are found in $57.9 \%$ cases of congenital heart diseases. The risk factors include consanguineous marriage, family history of congenital heart diseases, old maternal and paternal age, and exposure to teratogens, and genetic factors. Missteps in cardiac development are the main pathophysiology of congenital heart diseases. Ultrasonography screening in 18-22 weeks gestational age is utilized to screen. Followup screening can increase detection rate to $80 \%$. This study has limitation of only discussing most common congenital heart diseases and did not delve into rarer types of congenital heart diseases and did not discuss impacts or burden of congenital heart diseases in adulthood and health comorbidities associated. This literature review is beneficial for general practitioners and obstetricians focusing in maternal fetal medicine.
\end{abstract}


and additional screenings can detect up to $80 \%$ cases of congenital heart diseases. ${ }^{1}$ Prenatal screening for congenital malformations, including congenital heart diseases, increasing in popularity since 1980s and is typically done at 18-22 weeks of gestation. 1,6,7

Atrial septal defect, ventricular septal defect, and atrioventricular septal defect are typically shown as right-to-left shunts in ultrasonography and classified based on anatomical location of defects. 1,7 Because of placental circulation, which provides oxygen and nutrients, the majority of fetuses with congenital heart diseases showed no heart failure symptoms in utero. Following birth, with closure of the fetal circulation shunt, symptoms of heart failure is manifested clearly. ${ }^{6}$

Left side obstruction can manifest as systemic hypoperfusion with acidosis, particularly in ductusdependent circulation, as in Hypoplastic Left Heart Syndrome (HLHS), aortic stenosis, and Coarctation of Aorta (CoA). These congenital heart diseases can be detected during antenatal care using three-vessel and tracheal view (3VT). In cases of ductus-dependent pulmonary circulation, such as in pulmonal atresia, right-sided obstruction can manifest as significant cyanosis. 6

Intrauterine screening of otherwise normal fourchamber-view, such as Tetralogy of Fallot (ToF) and Transposition of Great Arteries (TGA), is possible with four-chamber-view with outflow tracts. 6 Closure or restriction of the foramen ovale can cause severe cyanosis and circulatory collapse in the transposition of great arteries where the systemic and pulmonal circulations work in tandem. Besides that, oxygenated and non-oxygenated blood are mixed. 6

Intrauterine congenital heart diseases detection is difficult in present times because of gestational age, complex heart structure in ultrasonography, training and experience, fetal and maternal movement, maternal obesity, amniotic fluids, fetal position, and maternal tissues. This screening is usually done with ultrasonography and conducted by general practitioners or obstetrician and gynecologists. It consists of preliminary screening at $18 \square 22$ weeks of gestation and follow-up screening to improve the accuracy (with up to $80 \%$ of accuracy is achievable in congenital heart diseases-focused screening). ${ }^{7}$

Preliminary screening increases the likelihood of detection and intervention, with the ultimate goal of lowering congenital heart diseases morbidity and mortality. Even with trainings, some congenital heart diseases, such as Total Anomalous Pulmonary Venous Drainage (TAPVD), coarctation of aorta, and progressive valvular abnormalities are still difficult to detect. 6

This literature review aims to describe the prevalence, anatomy, embryology, and ultrasonographic findings of congenital heart diseases, as well as other screening methods, like genetic polymorphisms, biomarkers, and artificial intelligence.

\section{Prevalence and Causes}

Congenital heart diseases are structural abnormalities of heart or major vessels that occur before birth. Ventricular Septal Defect (VSD), Atrial Septal Defect (ASD), Patent Ductus Arteriosus (PDA), pulmonary stenosis, Tetralogy of Fallot (ToF), Transposition of Great Arteries (TGA), Atrioventricular Septal Defect (AVSD), and Coarctation of Aorta (CoA) are the top eight congenital heart diseases globally. ${ }^{3,8}$ Congenital heart diseases are found around the world and affect millions of babies every year. It is responsible for one-third of all congenital anomalies found each year. ${ }^{2}$

Congenital heart diseases prevalence varied over time. Congenital heart diseases were found in 0.6 births per 1,000 live births on 1930, rising to 9.1 births per 1,000 live births after 1995. Incidence rate rose sharply from 1930 to 1960, then plateaued at around 5.3 births per 1,000 live births from 1961 to 1975 , before rising sharply again in $1975 \square 1995 .^{2,3}$

The three most common congenital heart diseases are ventricular septal defect, atrial septal defect, and patent ductus arteriosus. These three lesions account for $57.9 \%$ of congenital heart diseases cases worldwide, up from $49.2 \%$ in $1970-1974$ to $65.3 \%$ in $2010 \square 2017.3$ There is regional variation, with pulmonal outflow obstruction being more common in Asia than left ventricle outflow obstruction. Asia has also fewer TGA cases than in Europe, North and South America, and 
Oceania. ${ }^{2}$

There are numerous risk factors for congenital heart diseases. Consanguineous marriage (OR 2.34; 95\% CI

$1.61 \square 3.38)$, family history of congenital heart diseases
(OR 9.43; 95\% CI 3.30 $\square 27.02$ ), maternal comorbidities (OR 3.9; 95\% CI 1.2 $\square$ 5.6), and low birth weight (OR $3.11 ; 95 \%$ CI $1.84 \square 5.29)$ were all identified as major risk factors in a study conducted in Pakistan. ${ }^{9}$

Table 1. Global Congenital Heart Disease Prevalence

\begin{tabular}{lcc}
\hline $\begin{array}{c}\text { Congenital heart } \\
\text { diseases subtypes }\end{array}$ & $\begin{array}{c}\text { Prevalence per 1,000 live } \\
\text { births (95\% CI) }\end{array}$ & $\begin{array}{c}\text { Subtype percentage } \\
\text { (95\% CI) }\end{array}$ \\
\hline $\begin{array}{l}\text { Ventricular Septal } \\
\text { Defect }\end{array}$ & $3.071(2.845-3.305)$ & $35.568(33.876-37.278)$ \\
\hline Atrial Septal Defect & $1.441(1.215-1.687)$ & $15.378(13.492-17.363)$ \\
\hline $\begin{array}{l}\text { Patent Ductus } \\
\text { Arteriosus }\end{array}$ & $1.004(0.803-1.228)$ & $10.172(8.519-11.954)$ \\
\hline Pulmonary Stenosis & $0.546(0.485-0.611)$ & $6.233(5.703-6.784)$ \\
\hline Tetralogy of Fallot & $0.356(0.326-0.387)$ & $4.422(4.064-4.794)$ \\
\hline $\begin{array}{l}\text { Transposition of Great } \\
\text { Arteries }\end{array}$ & $0.295(0.269-0.322)$ & $3.819(3.446-4.210)$ \\
\hline $\begin{array}{l}\text { Atrioventricular Septal } \\
\text { Defect }\end{array}$ & $0.290(0.265-0.316)$ & $3.595(3.302-3.900)$ \\
\hline Coarctation of Aorta & $0.287(0.261-0.314)$ & $3.570(3.273-3.879)$ \\
\hline
\end{tabular}

Cited from: Liu et al., 2019

Meanwhile, a study in India found that paternal age above 25 years old (OR 1.943; 95\% CI 1.421 $\square 2.658$ ), no multivitamin intake in pregnancy (OR 2.853; 95\% CI 2.089 $\square 3.895$ ), first trimester fever history (OR 3.717; 95\% CI 1.625 8.501), obstetric issues history (OR 2.454; 95\% CI 1.565ロ3.848), and maternal age above 30 years old (OR 2.868; 95\% CI 1.255 $\square 6.555$ ) are congenital heart diseases risk factors. 10
Similar findings were found in a study that was conducted in Shaanxi, China. Multiple pregnancy, family history of congenital heart diseases, old maternal age, and parity were all found to be risk factors for congenital heart diseases. 11 Genetic factors, including chromosomal and syndromic, are known to play a role. Table 2 shows genetic factors in greater detail.

Table 2. Congenital Heart Disease Genetic Factors

\begin{tabular}{|c|c|c|c|}
\hline Syndrome & $\begin{array}{c}\text { Abnormalities of } \\
\text { genes/chromosomes }\end{array}$ & Lesions commonly found & Proportion \\
\hline Down & Trisomy 21 & AVSD, ASD, VSD, TOF & $40-50 \%$ \\
\hline Edwards & Trisomy 18 & $\begin{array}{l}\text { VSD, ASD, DORV, TOF, CoA, } \\
\text { HLHS }\end{array}$ & $90-100 \%$ \\
\hline Patau & Trisomy 13 & $\begin{array}{l}\text { ASD, VSD, DORV, HLHS, L- } \\
\text { TGA, AVSD, TAPVR, } \\
\text { dextrocardia, PDA }\end{array}$ & $80 \%$ \\
\hline Turner & Monosomy X & CoA, AS, HLHS, PAPVR & $25-35 \%$ \\
\hline Klinefelter & $47, \mathrm{XXY}$ & ASD, PDA, MVP & $50 \%$ \\
\hline Cat eye & Tetrasomy $22 p$ & TAPVR, PAPVR & $50 \%$ \\
\hline Pallister-Kilian & Tetrasomy $12 p$ & VSD, CoA, PDA, ASD, AS & $25 \%$ \\
\hline Velocardiofacial & Del 22q11.2 & $\begin{array}{l}\text { IAA(B), TA, TOF, aortic arch } \\
\text { anomalies }\end{array}$ & $75-85 \%$ \\
\hline Williams & Del 7q11.23 & SVAS \pm PVS, PS, PPS & $50-80 \%$ \\
\hline Alagille & $\begin{array}{l}\text { JAG1, NOTCH1 (del } \\
\text { 20p12) }\end{array}$ & PPS, TOF, ASD, PS & $85-95 \%$ \\
\hline Noonan & $\begin{array}{l}\text { PTPN11, SOS1, KRAS, } \\
\text { RAF1 }\end{array}$ & PVS, ASD, CoA, HCM & $80-90 \%$ \\
\hline Holt-Oram & TBX5 & ASD, VSD, AVSD, TOF & $80 \%$ \\
\hline Char & TFAP2B & PDA & $60 \%$ \\
\hline Ellis-van Creveld & $E V C, E V C 2$ & $\begin{array}{l}\text { Primum ASD, common atrium, } \\
\text { AVSD }\end{array}$ & $60 \%$ \\
\hline Smith-Lemli-Opitz & DHCR7 & $\begin{array}{l}\text { AVSD, primum ASD, VSD, } \\
\text { PAPVR }\end{array}$ & $45 \%$ \\
\hline CHARGE & CHD7, SEMA3E & $\begin{array}{l}\text { ASD, VSD, valvular } \\
\text { abnormalities }\end{array}$ & $50-80 \%$ \\
\hline Kabuki & $M L L 2$ & $\mathrm{CoA}, \mathrm{ASD}, \mathrm{VSD}$ & $40 \%$ \\
\hline Heterotaxy & ZIC3 & $\begin{array}{l}\text { Dextrocardia, L-TGA, AVSD, } \\
\text { TAPVR }\end{array}$ & $90-100 \%$ \\
\hline
\end{tabular}


ASD: atrial septal defect; AS: aortic stenosis; AVSD: atrioventricular septal defect; CoA: coarctation of aorta; DORV: double outlet right ventricle; HCM: hypertrophic cardiomyopathy; HLHS: hypoplastic left heart syndrome; IAA(B): interrupted aortic arch (type B); L-TGA: congenitally corrected transposition of great arteries; MVP: mitral valve prolapse; PAPVR: partial anomalous pulmonary venous return; PDA: patent ductus arteriosus; PPS: peripheral pulmonary stenosis; PS: pulmonary stenosis; PVS: pulmonary valve stenosis; SVAS: supravalvular aortic stenosis; TA: truncus arteriosus; TAPVR: total anomalous pulmonary venous return; TOF: tetralogy of Fallot; VSD: ventricular septal defect

\section{Cited from: Blue, et al. 2012.}

Non-syndromic genetic mutations, in addition to syndromic genetic factors, play a role in congenital heart diseases; as shown on Table 3. Table 3 lists the mutations that have been linked to congenital heart diseases.

Table 3. Congenital Heart Diseases Non-syndromic Genetic Factors

\begin{tabular}{|c|c|c|}
\hline Gene & Function & $\begin{array}{ll}\text { Lesions } \\
\end{array}$ \\
\hline NKX2-5 & Transcription factor & $\begin{array}{l}\text { ASD-AV block, TF, HLHS, TGA, DORV, Ebstein } \\
\text { anomaly, VSD }\end{array}$ \\
\hline NKX2-6 & Transcription factor & TA \\
\hline GATA4 & Transcription factor & ASD $\pm P S, T O F, V S D, D O R V$ \\
\hline GATA6 & Transcription factor & TA, TOF, AVSD \\
\hline$T B X 1$ & Transcription factor & IAA, aortic arch anomalies, VSD \\
\hline$T B X 5$ & Transcription factor & ASD, VSD, AVSD, conduction anomalies \\
\hline TBX20 & Transcription factor & ASD, VSD, valvular disease, LVOTO \\
\hline CITED2 & Transcription factor & ASD, VSD, TOF, TGA \\
\hline ZIC3 & Transcription factor & Heterotaxy, ASD, AVSD, TGA, VSD, TAPVR, PS \\
\hline ZFPM2 & Transcription factor & TOF \\
\hline FOXH1 & Transcription factor & TOF, VSD \\
\hline HAND1 & Transcription factor & HLHS (somatic mutation) \\
\hline TFAP2B & Transcription factor & PDA \\
\hline NOTCH1 & $\begin{array}{l}\text { Membrane-ligand } \\
\text { receptor }\end{array}$ & AS, BAV \\
\hline NODAL & $\begin{array}{l}\text { Membrane-ligand } \\
\text { receptor }\end{array}$ & Heterotaxy, TGA \\
\hline$J A G 1$ & $\begin{array}{l}\text { Membrane-ligand } \\
\text { receptor }\end{array}$ & PS, TOF \\
\hline CFC1 & $\begin{array}{l}\text { Membrane-ligand } \\
\text { receptor }\end{array}$ & Heterotaxy, TGA, DORV, TOF \\
\hline MYH6 & Sarcomere protein & ASD \\
\hline MYH7 & Sarcomere protein & ASD, Ebstein anomaly \\
\hline MYH11 & Sarcomere protein & PDA \\
\hline$A C T C 1$ & Sarcomere protein & ASD, VSD \\
\hline GJA 1 & $\begin{array}{l}\text { Gap junction } \\
\text { protein }\end{array}$ & HLHS (somatic mutation) \\
\hline GJA5 & $\begin{array}{l}\text { Gap junction } \\
\text { protein }\end{array}$ & TOF \\
\hline CRELD1 & $\begin{array}{l}\text { Cellular matrix } \\
\text { protein }\end{array}$ & AVSD, dextrocardia \\
\hline$E L N$ & Structural protein & SVAS \\
\hline VEGFA & Mitogen & TOF \\
\hline
\end{tabular}

ASD: atrial septal defect; AS: aortic stenosis; AV: atrioventricular; AVSD: atrioventricular septal defect; BAV: bicuspid aortic valve; DORV: double outlet right ventricle; HLHS: hypoplastic left heart syndrome; IAA: interrupted aortic arch; LVOTO: left ventricular outflow tract obstruction; PDA: patent ductus arteriosus; PS: pulmonary stenosis; SVAS: supravalvular aortic stenosis; TA: truncus arteriosus; TAPVR: total anomalous pulmonary venous return; TGA: transposition of great arteries; TOF: tetralogy of Fallot; VSD: ventricular septal defect.

Cited from: Blue et al., 2012. 
Furthermore, environmental and infectious factors can cause congenital heart diseases, as shown on Table
4 below, which lists environmental or infectious risk factors for congenital heart diseases.

Table 4. Congenital Heart Diseases Environmental and Infectious Factors

\begin{tabular}{|l|l|l|}
\hline \multicolumn{1}{|c|}{ Teratogen } & \multicolumn{1}{|c|}{ Lesions commonly found } & \multicolumn{1}{c|}{ Risks } \\
\hline Maternal diabetes & $\begin{array}{l}\text { VSD, ASD, L-TGA, AVSD, TAPVR, CoA, } \\
\text { TOF, TGA }\end{array}$ & $5 \%$ \\
\hline Maternal rubella & PDA, VSD, ASD, PS, TOF & $30-60 \%$ \\
\hline Maternal phenylketonuria & TOF, VSD, PDA, left heart lesions & $15-50 \%$ \\
\hline $\begin{array}{l}\text { Systemic lupus } \\
\text { erythematosus }\end{array}$ & Complete heart block & Unknown \\
\hline Fever in pregnancy & $\begin{array}{l}\text { PS, left-sided and right-sided } \\
\text { obstruction defects, tricuspid atresia, } \\
\text { VSD }\end{array}$ & Unknown \\
\hline Thalidomide & TOF, ASD, VSD, TA & Up to 30\% \\
\hline Retinoic acids & TA, TOF, IAA, DORV & $25 \%$ \\
\hline Anticonvulsants & All common defects & Unknown \\
\hline Lithium & Ebstein anomaly, tricuspid atresia & Unknown \\
\hline $\begin{array}{l}\text { Selective serotonin reuptake } \\
\text { inhibitors }\end{array}$ & VSD, ASD, TOF & Unknown \\
\hline Alcohol & VSD, ASD, TOF & Unknown \\
\hline Marijuana & VSD, Ebstein anomaly & \\
\hline
\end{tabular}

ASD: atrial septal defect; AS: aortic stenosis; AV: atrioventricular; AVSD: atrioventricular septal defect; BAV: bicuspid aortic valve; CoA: coarctation of aorta; DORV: double outlet right ventricle; HLHS: hypoplastic left heart syndrome; IAA: interrupted aortic arch; LVOTO: left ventricular outflow tract obstruction; PDA: patent ductus arteriosus; PS: pulmonary stenosis; SVAS: supravalvular aortic stenosis; TA: truncus arteriosus; TAPVR: total anomalous pulmonary venous return; TGA: transposition of great arteries; TOF: tetralogy of Fallot; VSD: ventricular septal defect.

Cited from: Blue et al., 2012.

Methylenetetrahydrofolate reductase (MTHFR) is an important enzyme the metabolism of folate. Methylenetetrahydrofolate reductase converts 5,10methylenetetrahydrofolate into 5-methylhydrofolate, which is folic acid's active form. Methylenetetrahydrofolate reductase is known to reduce folate bioavailability, which is necessary for homocysteine re-methylation into methionine. At 37oC, C677T polymorphism of MTHFR gene produces thermolabile enzyme that reduces activity of methylenetetrahydrofolate reductase. 13,14 MTHFR gene is located on the short arm of chromosome 1 (1p36.22), and it has 13 exons with total length of 20,373 base pairs. ${ }^{15}$

In Asian populations, the MTHFR C677T is known to be associated with congenital heart diseases. This polymorphism is thought to cause folate metabolic synthesis dysfunction, which leads to a decrease in methionine, an essential amino acid, synthesis. 15,16 The C677T polymorphism causes alanine to be substituted for valine in the catalytic domain of the enzyme, lowering enzyme activity by up to $35 \%$ in heterozygotic individuals and up to $70 \%$ in homozygotic individual due to decrease of enzyme thermostability. ${ }^{15,17}$ Congenital heart disease risk is reduced with adequate maternal folic acid intake. Hyperhomocysteinemia is a known risk factor for congenital heart disease, methylenetetrahydrofolate reductase activity is known to affect homocysteine plasma concentration. ${ }^{13,16}$ Congenital heart disease is more common in Asian population who have homozygous 677CC polymorphism.16 MTHFR polymorphism causes DNA hypomethylation and raises plasma homocysteine, resulting in folic acid deficiency. ${ }^{15}$ In a meta-analysis, the MTHFR C677T allele polymorphism was found to be a risk factor for congenital heart disease in Asians, while the A1298C polymorphism was found to be a risk factor in Caucasians. ${ }^{18}$ According to another meta-analysis, the MTHFR C677T polymorphism is a significant risk factor 
for congenital heart disease in Asian population, but not in Caucasian population. The MTHFR A1298C polymorphism does not appear to be a significant risk factor for congenital heart disease, according to the findings of this meta-analysis. ${ }^{19}$ Another meta-analysis shows that MTHFR C677T polymorphism plays a significant risk factor for congenital heart disease in Caucasian population. ${ }^{20}$

\section{Embryology of Heart}

The heart begins to form in the third week of gestation. Cardiac cells emerge from mesodermal layers in cranial area, migrating to the primary heart field (cranial of neural folds), and begin to form parts of the atria and the entire left ventricle. The right ventricle and outflow tracts emerge from the visceral side of the mesoderm's secondary heart field. 21,22

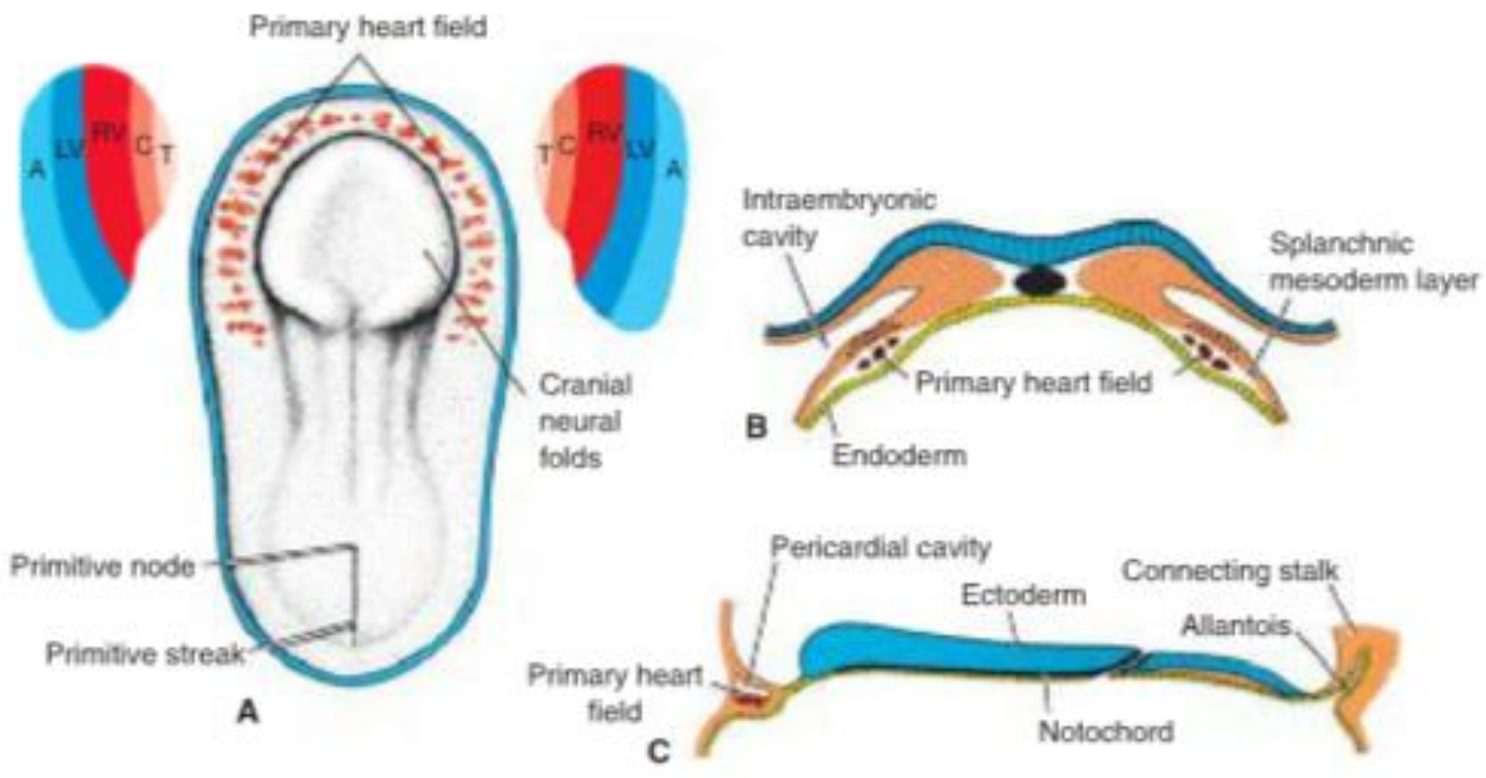

Figure 1. Heart embryology. (A) Dorsal view of 18-days old embryo. Progenitor cells of heart migrate and form primary heart field in the shape of a horseshoe. The primary heart field forms both the right and left sides of the heart, including both atrium and whole left ventricle. Secondary heart field gives rise to the right ventricle, outflow tract, and truncus arteriosus; (B) transverse view of primary heart field in visceral mesoderm; (C) lateral cut on embryo showing primary heart field.

Cited from: Sadler, 2019

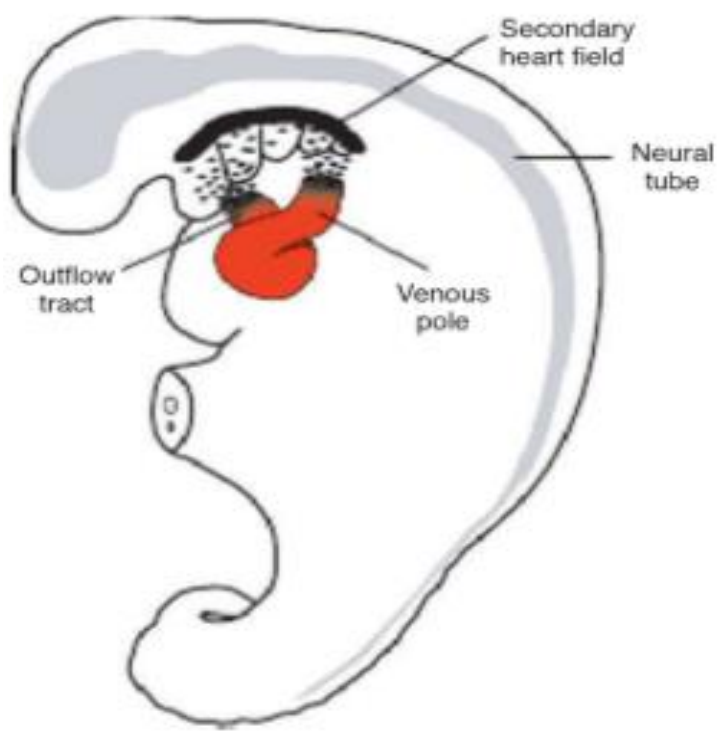


Figure 2. Secondary heart field in visceral mesoderm. The secondary heart field rises elongation of artery and vein poles, encompassing right ventricle and outflow tract (conus cordis and truncus arteriosus), atrium, and sinus venosus. Secondary heart field defect causes shortening and outflow defect.

\section{Cited from: Sadler, 2019}

At first, central part of cardiogenic area is located on the anterior of oropharyngeal membrane and neural plate. The oropharyngeal membrane pulls anteriorly and heart moves cervically during neural tube closure and brain formation, before migrating to the thorax. 21,22 During the period of cephalocaudal embryo development, the embryo also folds laterally, forming outflow and heart ventricles. During embryo development, the heart develops into a complete tube made of endothelial and myocardium cells. The middle section of mesocardium gradually disappears, leaving a transverse pericardial sinus that connects both sides of the pericardial cavity. ${ }^{22}$

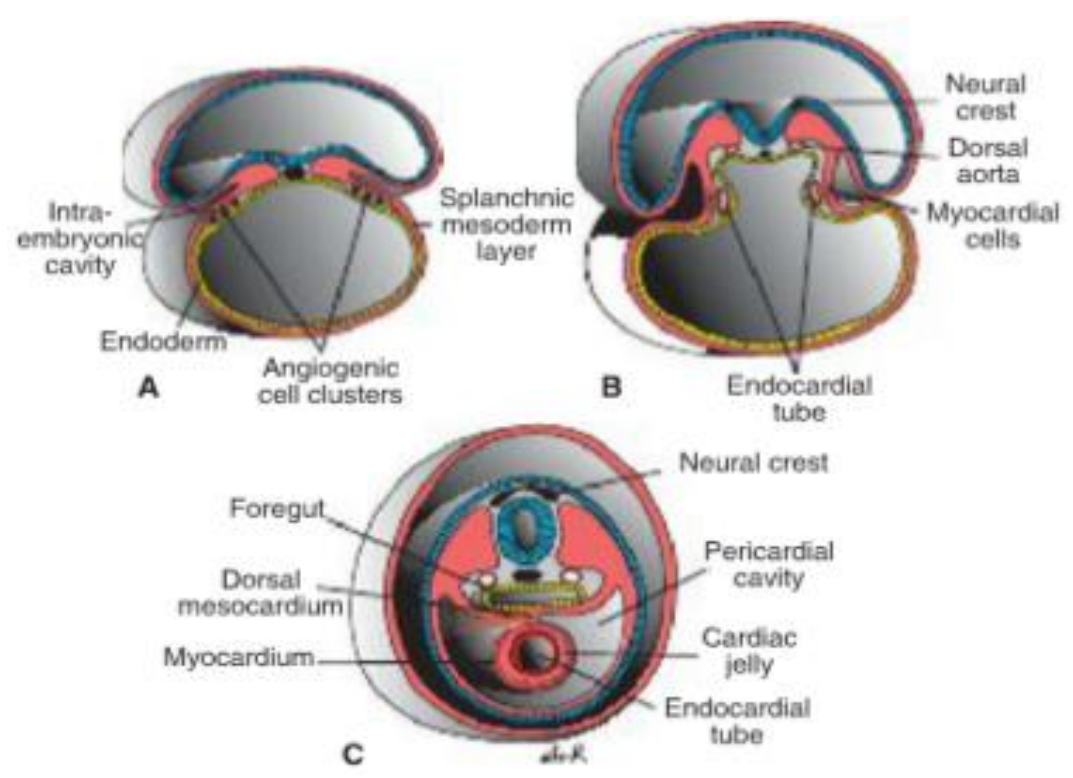

Figure 3. Cross-section of embryo in heart development; (A) 17-days old embryo; (B) 18-days old embryo; (C) 22-days old embryo. Caudal area of tube forms a fusion. Outflow and majority of ventricles are created from the expansion of the horseshoe-shaped area.

\section{Cited from: Sadler, 2019}

Heart undergoes elongation from cells arising from secondary heart field to create right ventricle and outflow tracts. Outflow defects, including ventricular septal defect, tetralogy of Fallot, pulmonary atresia, and pulmonary stenosis, come from disruptions in this stage. 22 During the outflow elongation, the cardiac tube begins to fold on the 23rd day to form cardiac loop, which finishes on the $28^{\text {th }}$ day. ${ }^{21,22}$ 

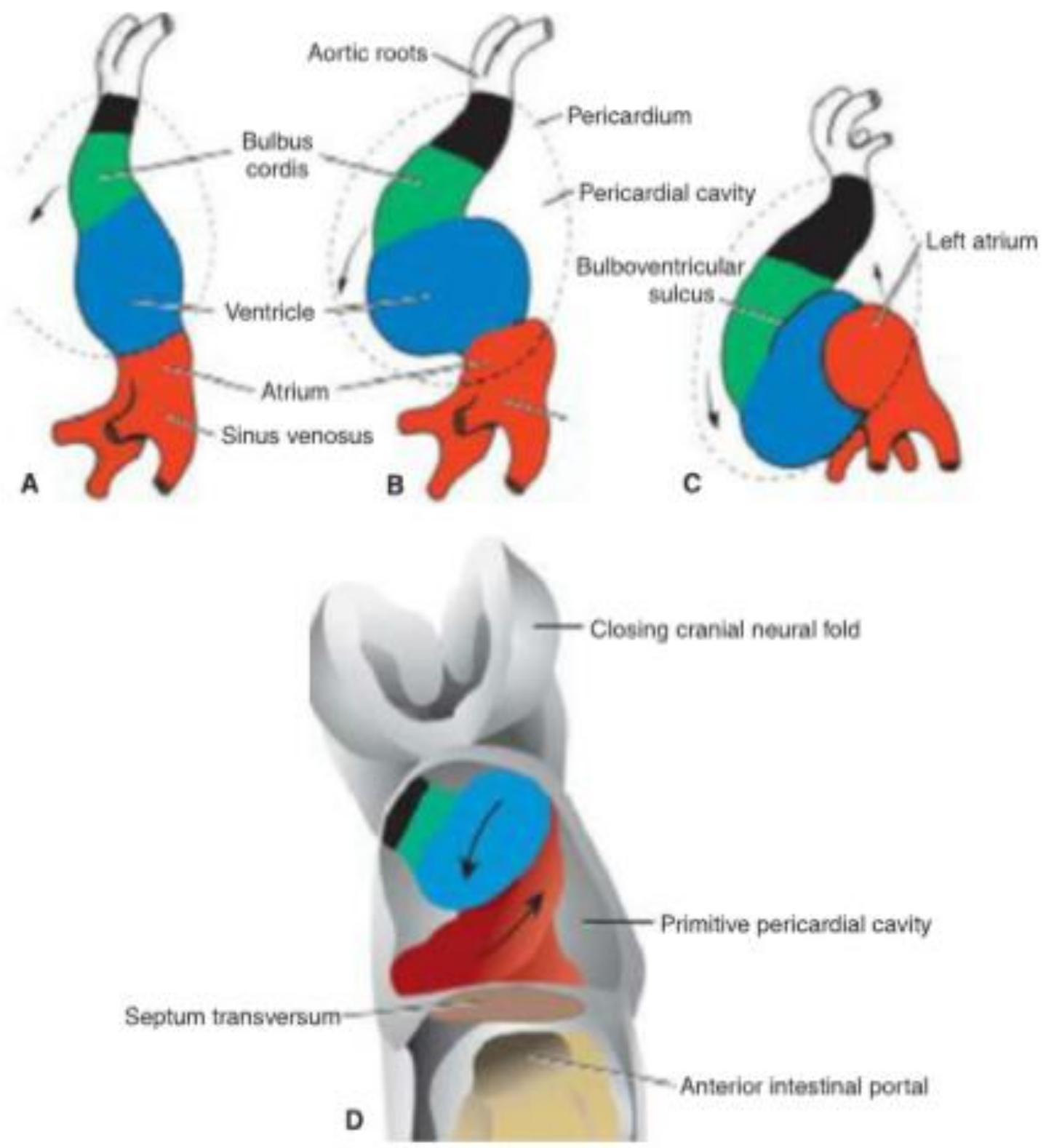

Figure 4. Formation of cardiac loop; (A) 22 days; (B) 23 days; (C) 24 days; (D) frontal view of looping heart tube. Primitive ventricles move ventrally and to the right, while atria move dorsally and to the left.

\section{Cited from: Sadler, 2019}

Cardiac septum develops on $27^{\text {th }}$ day until $37^{\text {th }}$ day. Endocardial cushions from around the atrioventricular and conotruncal area to form the septum of the atrium and the ventricles as the tissues develop. Atrioventricular canals and valves are formed by the same process. Atrial septal defect, ventricular septal defect, transposition of great arteries, and tetralogy of Fallot are all caused by the disruption of development at this stage. 21,22 

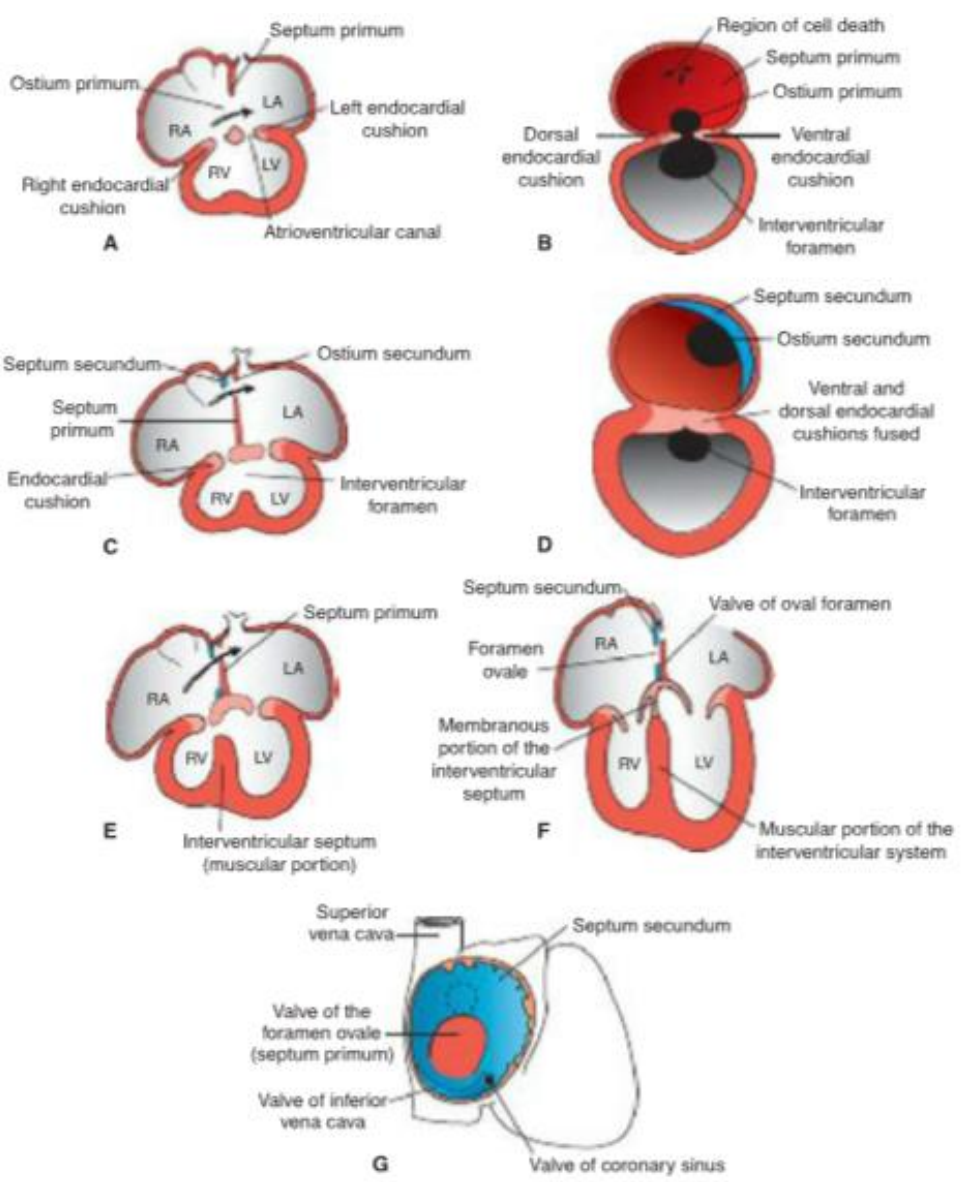

Figure 5. Septum on different development stages. (A, B) 30 days; (C, D) 33 days; $(E) 37$ days; $(F$, G) neonates.

Cited from: Sadler, 2019

Table 5. Lesions Associated with Various Developmental Stages

\begin{tabular}{|c|c|c|c|}
\hline Tissues & $\begin{array}{c}\text { Cellular processes } \\
\text { involved }\end{array}$ & Normal process & Abnormalities \\
\hline $\begin{array}{l}\text { Primary heart field } \\
\text { (16th day until } 18^{\text {th }} \\
\text { day) }\end{array}$ & $\begin{array}{l}\text { Laterality and } \\
\text { patterning }\end{array}$ & $\begin{array}{l}\text { Formation of four } \\
\text { heart chambers }\end{array}$ & $\begin{array}{l}\text { Double outlet right } \\
\text { ventricle, } \\
\text { transposition of } \\
\text { great arteries, atrial } \\
\text { septal defect, } \\
\text { ventricular septal } \\
\text { defect, atrial } \\
\text { isomerism, } \\
\text { ventricular } \\
\text { inversion, } \\
\text { dextrocardia }\end{array}$ \\
\hline $\begin{array}{l}\text { Heart tube (22nd day } \\
\text { until } 28^{\text {th }} \text { day) }\end{array}$ & $\begin{array}{l}\text { Genetic signal to } \\
\text { create normal loop }\end{array}$ & Cardiac loop & Dextrocardia \\
\hline $\begin{array}{l}\text { Atrioventricular } \\
\text { canal, endocardial } \\
\text { cushions (26th day } \\
\text { until 35th day) }\end{array}$ & $\begin{array}{l}\text { Formation of } \\
\text { endocardial } \\
\text { cushions, } \\
\text { proliferation and } \\
\text { cellular migration }\end{array}$ & $\begin{array}{l}\text { Division of } \\
\text { atrioventricular } \\
\text { canal to right and } \\
\text { left canal, } \\
\text { formation of mitral } \\
\text { and tricuspid valve, } \\
\text { formation of } \\
\text { interventricular } \\
\text { septum }\end{array}$ & $\begin{array}{l}\text { Ventricular septal } \\
\text { defect, mitral and } \\
\text { tricuspid defect }\end{array}$ \\
\hline
\end{tabular}




\begin{tabular}{|c|c|c|c|}
\hline $\begin{array}{l}\text { Secondary heart } \\
\text { field ( } 22^{\text {nd }} \text { day until } \\
28^{\text {th }} \text { day) }\end{array}$ & $\begin{array}{l}\text { Visceral mesoderm } \\
\text { from ventral } \\
\text { pharynx and } \\
\text { signals from neural } \\
\text { crest cells }\end{array}$ & $\begin{array}{l}\text { Elongation and } \\
\text { separation of } \\
\text { outflow into aortic } \\
\text { and pulmonary } \\
\text { canal }\end{array}$ & $\begin{array}{l}\text { Tetralogy of Fallot, } \\
\text { transposition of } \\
\text { great arteries, } \\
\text { pulmonary atresia, } \\
\text { pulmonary stenosis }\end{array}$ \\
\hline $\begin{array}{l}\text { Outflow tract (36 } \\
\text { day until 49th day) }\end{array}$ & $\begin{array}{l}\text { Migration of neural } \\
\text { crest cell, } \\
\text { proliferation }\end{array}$ & $\begin{array}{l}\text { Formation of } \\
\text { conotruncal } \\
\text { cushions and } \\
\text { division of outflow } \\
\text { tract }\end{array}$ & $\begin{array}{l}\text { Common truncus } \\
\text { arteriosus, outflow } \\
\text { defect }\end{array}$ \\
\hline $\begin{array}{l}\text { Aortic arch }\left(22^{\text {nd }}\right. \\
\text { day until } 42^{\text {nd }} \text { day) }\end{array}$ & $\begin{array}{l}\text { Migration of neural } \\
\text { crest cell, } \\
\text { proliferation }\end{array}$ & $\begin{array}{l}\text { Formation of aortic } \\
\text { arch }\end{array}$ & $\begin{array}{l}\text { Anomalous right } \\
\text { pulmonary artery }\end{array}$ \\
\hline
\end{tabular}

\section{Cited from: Sadler, 2019}

\section{Ultrasonography in Congenital Heart Diseases}

Ultrasonography is commonly used to screen for congenital heart diseases at 18-22 weeks of gestation.23,24 In British Isles, detection rate of congenital heart diseases was around 35\%. In United Kingdom, prenatal screening is able to detect $35 \%$ of congenital heart diseases, but only $32 \%$ in Northern Ireland. Scotland, had a 36\% detection rate, while Wales had a $52 \%$ detection rate. The number is lower than the target of of $60 \%$ detection rate in British Isles. 24

Around one-third of congenital heart diseases could be screened prenatally in a study in Czech. The detection rate for double outlet right ventricle was $77.3 \%$, 50.6\% for left heart hypoplasia, 50\% for Ebstein anomaly, 42.9\% for atrioventricular septal defect, and $42.5 \%$ for single ventricle. The rate of detection for atrial septal defect, ventricular septal defect, and pulmonary stenosis rate on the other hand were low;

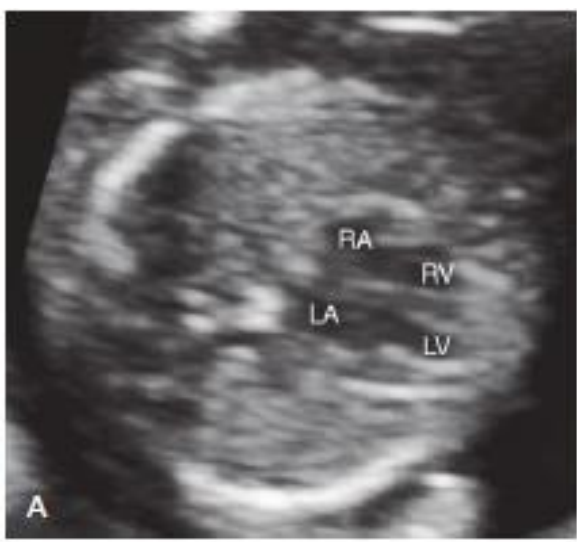

$0.8 \%, 2.4 \%$, and $3.2 \%$, respectively. ${ }^{23}$

Only $9.96 \%$ of congenital heart diseases were detected prenatally, according to a Brazilian study. Around $48.1 \%$ of the cases were complex (left heart hypoplasia, tricuspid atresia, Ebstein anomaly, truncus arteriosus), 18.5\% were significant (tetralogy of Fallot, large ventricular septal defect, tricuspid dysplasia, large pulmonary stenosis), $7.4 \%$ were minor (small ventricular septal defect), and $26 \%$ were not classified (cardiomyopathy, dysrhythmia, and others). 25

The four-chamber view can be used to screen for congenital heart diseases as early as 11 weeks of gestation. Following that, screening can be done from second trimester to monitor any septal or developmental abnormalities. In the 13th week of pregnancy, the sensitivity of congenital septal defect may approach $92 \% .^{7}$

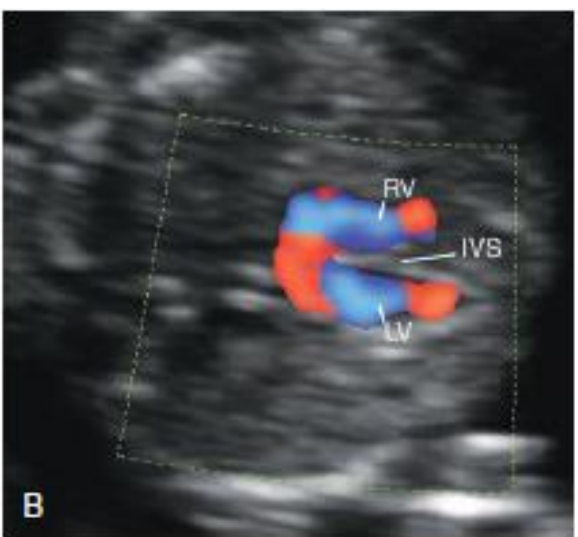

Figure 6. Four-chamber view in early gestation. (A) Four-chamber view in 13th week; (B) Four-chamber view with Doppler in 13th week.

Cited from: Norton, 2008 
Congenital heart diseases can be detected during the second trimester screening. Screenings are usually performed between week 18-22 of gestation. The goal of screening is to assess heart rate, heart size, heart position, as well as four chamber of the heart, pericardium, atrium, ventricles, atrioventricular junctions, and ventriculoatrial junctions. 7 Because of the clinical complications that can arise shortly after birth, early detection of congenital heart diseases is paramount.
Because of its high sensitivity and specificity, safety, and noninvasiveness, Doppler echocardiography is becoming a primary diagnostic tool in congenital heart diseases screening. 6,26 Determination of heart location, followed by four-chamber view, left ventricular outflow tract view, right ventricular outflow tract view, and three-vessel view or three-vessel tracheal view are the steps of echocardiography. 6 The purpose of these examinations are to determine the cardiac shape and the cardiac abnormalities. 27
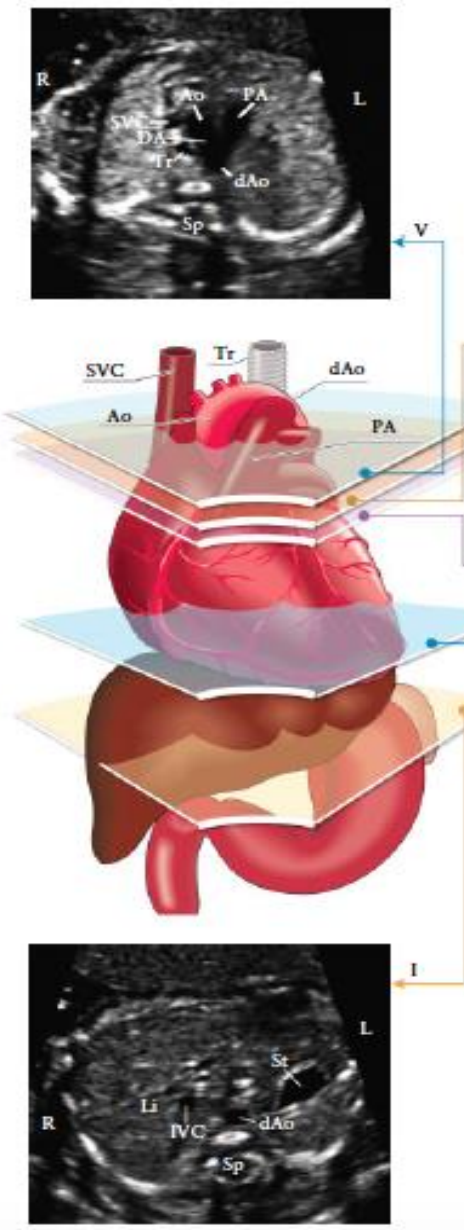

IV

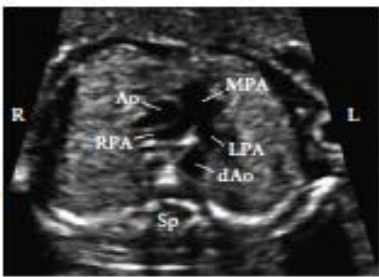

III
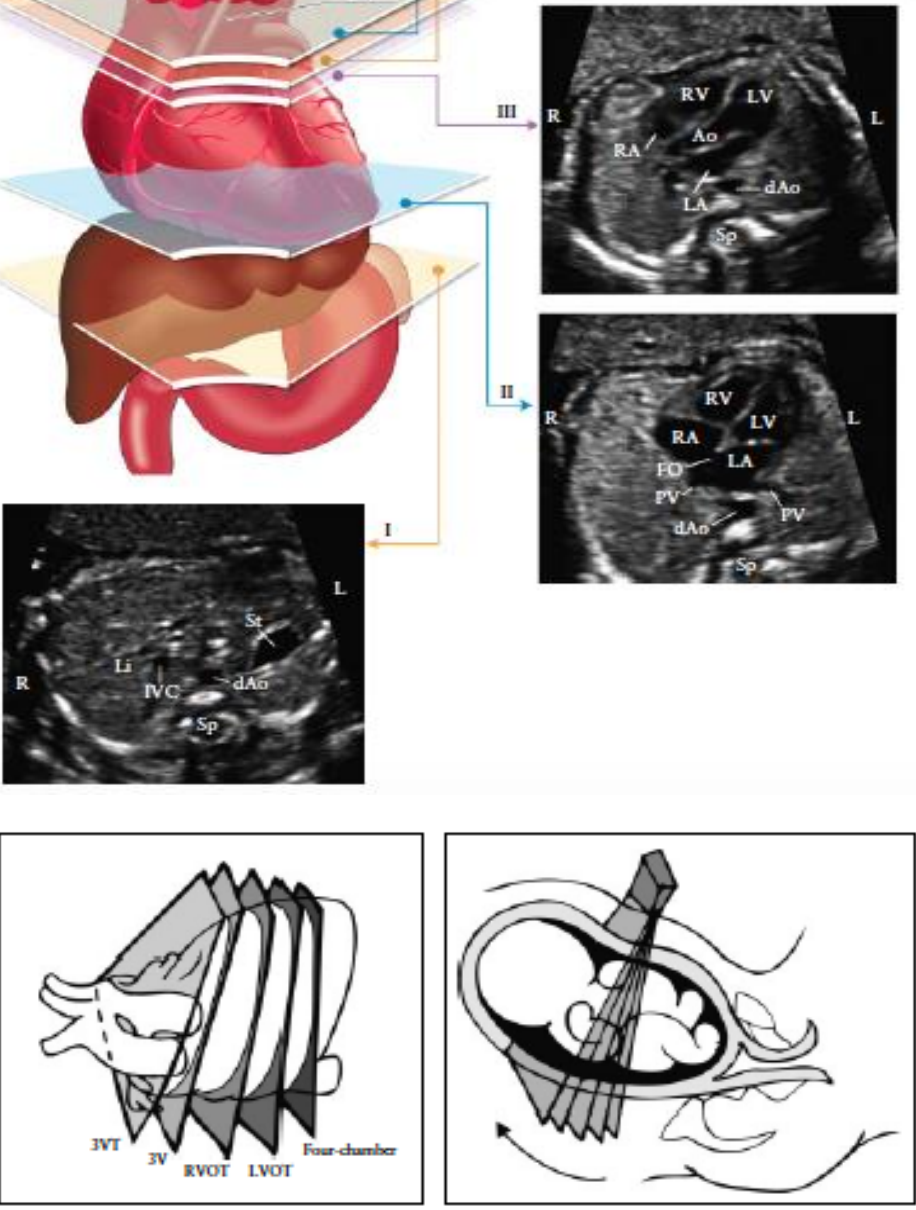

Figure 7. Main axis of fetal heart screening. I: most caudal plane, showing fetal stomach (St), descending aorta cross section (dAo), spine (Sp), and fetal liver (Li). II: four-chamber view of fetal heart, showing right and left ventricle (RV, LV), atria (RA, LA), foramen ovale (FO), and pulmonary veins beside descending aorta. III: left ventricular outflow tract view, showing aorta (Ao), LV, RV, LA, and RA with descending aorta cross section (dAo). IV: most cephalad position (right 
ventricular outflow tract view) showing pulmonary artery (MPA) and its branches (RPA dan LPA), ascending aorta (Ao), and descending aorta (dAo). V: three vessels tracheal view show superior vena cava (SVC), pulmonary artery (PA), ductus arteriosus (DA), aortic arch (Ao-dAo), and trachea (Tr).

\section{Cited from: The International Society of Ultrasound in Obstetrics, 2013}

Cardiac location screening is required to determine cardiac orientation. Other lesions can sometimes be found in situs inversus, so more thorough screening is required. Four-chamber-view is used to determine the location and anomalies of the heart, as well as surrounding tissues lesions, tetralogy of Fallot, cardiomegaly, and septal or valvular defects. 6,28 Fetal heart rhythm and heart rate are also measured using the four-chamber view. Heart block can cause persistent bradycardia. Abnormalities in thoracal cavity, such as diaphragmatic hernia or pulmonary hypoplasia, can cause abnormal heart location. 27

Valvular defect, aortal defect, and ventricular septal defect can be determined using the left ventricular outflow tract view. Right ventricular outflow tract view is used to determine right heart outflow, which includes pulmonary valve, pulmonary stenosis, and transposition of the great arteries. 6,26,28

Three-vessels view and three-vessel tracheal view can be utilized to determine any congenital heart defects and to confirm defects detected in fourchamber-view ultrasonography. Three-vessel-view can also be used to help in determining the diagnosis of syndromic chromosomal abnormalities. 6,26,28

A follow-up examination is sometimes recommended. Autoimmune antibody, family history of defects, in vitro fertilization, maternal metabolic disease, or teratogenic exposure are some of maternal indications. Abnormal screening results, a family history of congenital heart diseases, an abnormal heart rhythm, chromosomal abnormalities, extracardiac abnormalities, hydrops, or monochorionic twin pregnancy are some of fetal indications. 29

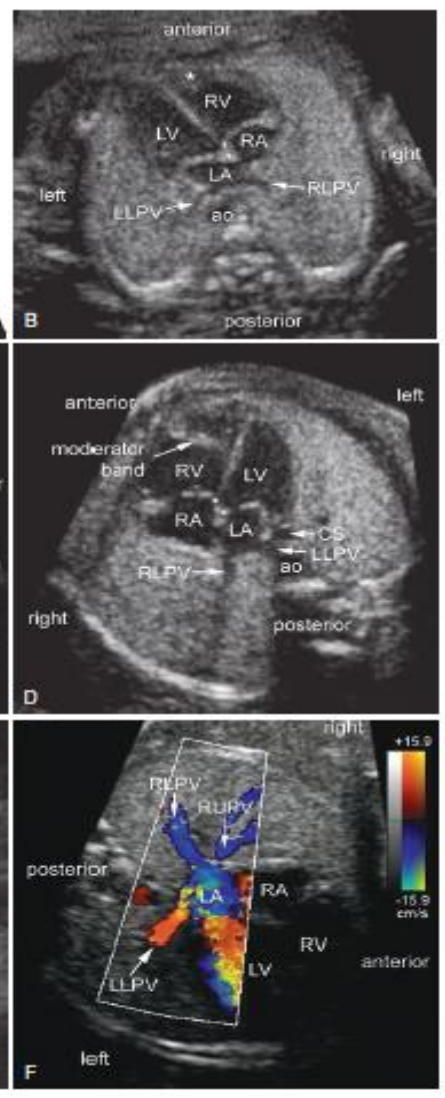

Figure 8. Four-chamber view on second trimester. (A) Diagram; (B-F) Ultrasonographic findings.

Cited from: Norton, 2008 


\section{Clinical Symptoms and Examination Required}

Table 6. Clinical Symptoms of Congenital Heart Lesions

\begin{tabular}{|c|c|c|c|}
\hline Lesions & $\begin{array}{c}\text { Prevalence per } \\
10,000 \text { live } \\
\text { births }\end{array}$ & Hypoxemia & $\begin{array}{c}\text { Ductus } \\
\text { arteriosus } \\
\text { dependent }\end{array}$ \\
\hline Tetralogy of Fallot & 5.1 & Majority & Rare \\
\hline Transposition of great arteries & 4.0 & All & Rare \\
\hline Double-outlet right ventricle & 1.7 & Some & Not \\
\hline Truncus arteriosus & 1.0 & All & Not \\
\hline $\begin{array}{l}\text { Total anomalous pulmonary } \\
\text { venous connection }\end{array}$ & 1.2 & All & Not \\
\hline Ebstein anomaly & 0.6 & Some & Sone \\
\hline Tricuspid atresia & 0.5 & All & Some \\
\hline $\begin{array}{l}\text { Pulmonary atresia with intact } \\
\text { septum }\end{array}$ & 0.8 & All & All \\
\hline Pulmonary stenosis/atresia & 6.3 & Some & Some \\
\hline Right heart hypoplasia & 3.3 & All & All \\
\hline Coarctation of aorta & 4.7 & Some & Some \\
\hline Aortic arch atresia/hypoplasia & 1.0 & Some & All \\
\hline Aortic valve stenosis & 1.6 & Rare & Some \\
\hline Other defects & 12.4 & Some & Some \\
\hline
\end{tabular}

Cited from: Norton, 2008

Common lesions causing left-to-right shunts are atrial septal defect, ventricular septal defect, and patent ductus arteriosus. Shunt flow is affected by the size of defect and pulmonal resistance in an atrial septal defect. There are no cardiac enlargement are observed in small shunts; however, larger shunts can cause dilatation of right atrium and ventricle, middiastolic tricuspid murmur, and systolic murmur due to increased pulmonal flow. 30,31

The pathophysiology of patent ductus arteriosus and ventricular septal defect is similar. The degree of the shunt is determined from the size of the defect and the pulmonary vascular resistance. Ventricular septal defect is more commonly found in six to eight weeks of birth because of decrease in pulmonary vascular resistance in this age. A small defect will not result in increase of cardiac size or changes in electrocardiogram, whereas a larger defect will result in the enlargement of left atrium and ventricle. Meanwhile, aortic arch elongation or enlargement can be found in patent ductus arteriosus. Cyanosis can be seen in the lower limbs as pulmonary vascular resistance increases. ${ }^{30,31}$

Thorax $\mathrm{x}$-ray is crucial radiological examination. Cardiomegaly and pathognomonic heart shape can be assessed with thorax x-ray. Thorax x-ray can also be used to determine the size of large vessels. Echocardiography is utilized to evaluate cardiac shape, cardiac function (using Doppler echocardiography), and direct defect visualization. For surgical assessment and planning, MRI has been used to reconstruct threedimensional cardiac shape. 30,32

Proinflammatory cytokines, such as TNF-alpha, VEGF-D, and HB-EGF have been used to assess cardiac failure. ${ }^{33,34} \mathrm{TNF}$-alpha has cut-off value of 68 $\mathrm{pg} / \mathrm{mL}$ (sensitivity 50\%, specificity 93.4\%, positive predictive value 7.6 , negative predictive value 0.5 ). Meanwhile, the cut-off value of VEGF-D is $1156 \mathrm{pg} / \mathrm{mL}$ (sensitivity $50 \%$, specificity $93.4 \%$, positive predictive value 7.6 , negative predictive value 0.5$)$. The cut-off value of other biomarker, HB-EGF, is $90 \mathrm{pg} / \mathrm{mL}$ (sensitivity $83.3 \%$, specificity $83.6 \%$, positive predictive value 5.1, negative predictive value 0.2). When combined, these three biomarkers have 100\% sensitivity, $80.3 \%$ specificity, positive predictive value of 5.1 , and negative predictive value of 0.33

\section{Artificial Intelligence Role in Chd Screening}

Artificial intelligence can help to increase diagnostic and therapeutic accuracy. Machine learning is capable 
to analyze, manage, making decision based on the data available, and reflecting those decisions to improve accuracy in next step of the data process. Artificial intelligence is capable of making timely and effective decision with the help of additional data that has been gathered. The end result is a decrease in diagnostic errors. 35

Machine learning is type of computer modelling that involves teaching a computer to perform a task with specific goal in mind without explicitly telling it to do some tasks.36 Artificial intelligence can create and implement imaging protocols, reducing the amount of time and money spent required on imaging. 37 The medical team can use artificial intelligence to improve diagnosis, risk prediction, therapeutic decisionmaking, and workflow. 38 screening performed by a trained physician, computeraided ultrasonography promises similar accuracy. Automatic echocardiography analysis can improve cardiac structures and anomalies recognition. 39,42 In $75 \%$ of cases, an automatic screening using neural learning-based computer program can diagnose tetralogy of Fallot with $76 \%$ specificity. 43

There are two types of machine learning algorithm: supervised and unsupervised. Unsupervised learning can be taught using existing examples with the goal of recognizing pattern in a large amount of unrelated data. Supervised learning necessitates the preparation of prior ground truth, when the end goal of data processing is known, supervised learning is more commonly used. Whereas unsupervised learning is useful for data exploration and analysis. ${ }^{36}$

When compared to the same ultrasonographic

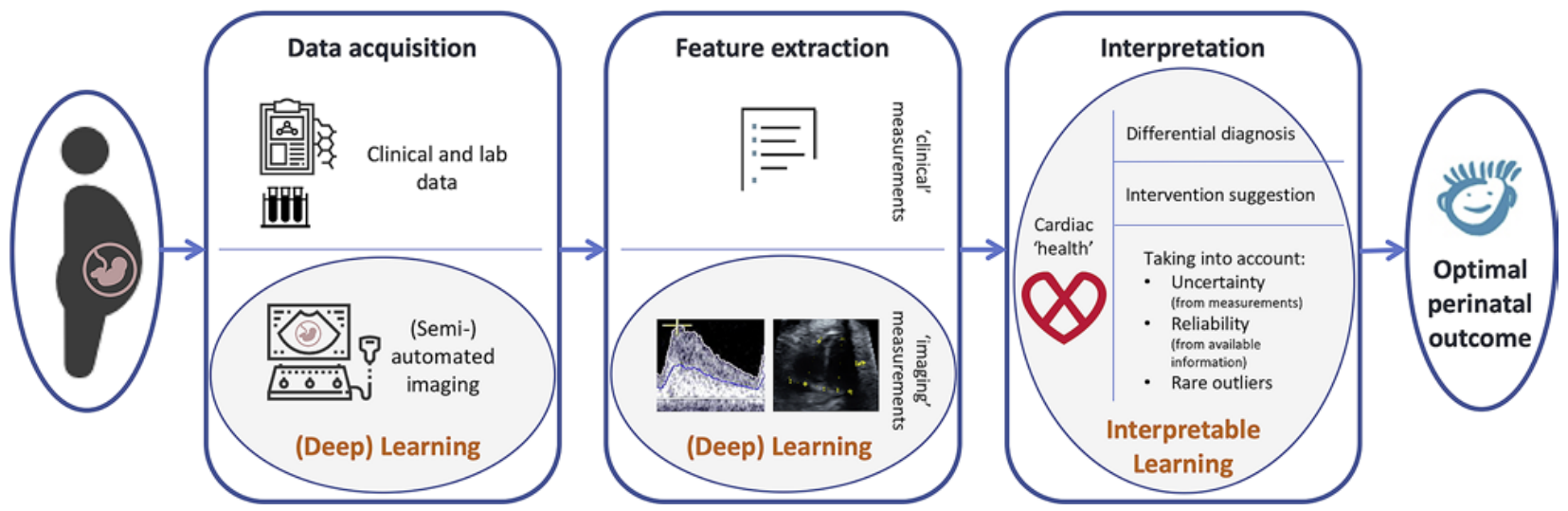

Figure 9. Machine Learning in Congenital Heart Disease. In the short term, machine learning can aid operators in fetal cardiac recognition, improving quality, and comprehension. Machine learning can extract key points from data, resulting in increased standardization and efficiency.

\section{Cited from: Garcia-Canadilla et al., 2020}

Machine learning is capable of identifying fetal cardiac features, assisting segmentation and measurement of cardiac structures, and distinguishing normal cardiac shape from data pool, especially when used in a supervised learning format.36 Artificial intelligence-based congenital heart defects recognition can recognize cardiac structures, distinguish them from surrounding tissues, and measure cardiac anomalies. 42

\section{Conclusion}

Congenital heart diseases affect 1.35 million children born every year, making them a major public health concern. To achieve an acceptable detection rate, better screening and follow-up should be conducted as the increasing rate of congenital heart diseases. Ventricular septal defect, atrial septal defect, and atrioventricular septal defect are found in $57.9 \%$ cases of congenital heart diseases worldwide, and this number is growing. Consanguineous marriage, family history of congenital heart diseases, old maternal and paternal age, and exposure to teratogens are all known to be the risk factors of congenital heart diseases. Congenital heart diseases are known to be caused by genetic factors, such as chromosomal or syndromic abnormalities.

The main pathophysiology of congenital heart 
diseases is flaws in cardiac development. Ultrasonography can be used to screen for developmental issues between 18 and 22 weeks of gestation. Follow-up screenings can be done to improve the detection rate to $80 \%$ or better.

Comorbidities associated with congenital heart diseases are one of the areas where more research can be conducted. Congenital diseases and cardiovascular risk factors in adulthood are also a promising field of research. Treatment options for congenital heart diseases, as well as risks and benefits associated with them, have emerged as a promising field of research.

\section{Acknowledgment}

The authors are grateful for thorough reviews and feedbacks provided by faculty members from the Division of Maternal Fetal Medicine, Department of Obstetrics and Gynecology, Mohammad Hoesin General Hospital Palembang, South Sumatera, Indonesia.

\section{References}

1. CunninghaJm F. Gary, Kenneth JL, Steven LB, Jodi SD, Barbara LH, Brian MC, et al. Williams obstetrics. 25th edition. New York: McGrawHill Education, 2018.

2. Van Der Linde D, Konings EEM, Slager MA, Witsenburg M, Helbing WA, Takkenberg JJM, et al. Birth prevalence of congenital heart disease worldwide: A systematic review and meta-analysis. J Am Coll Cardiol. 2011;58(21):2241-7.

3. Liu Y, Chen S, Zühlke L, Black GC, Choy MK, Li N, et al. Global birth prevalence of congenital heart defects 1970-2017: Updated systematic review and meta-analysis of 260 studies. Int $\mathrm{J}$ Epidemiol. 2019;48(2):455-63.

4. Manopo BR, Kaunang ED, Umboh A. Gambaran penyakit jantung bawaan di neonatal intensive care unit RSUP Prof. Dr. R. D. Kandou Manado periode 2013 - 2017. eCliniC. 2018;6(2):87-93.

5. Budi Junio Hermawan, Didik Hariyanto DA. Profil penyakit penyakit jantung bawaan di instalasi rawat inap anak RSUP dr. M. djamil Padang periode Januari 2013 - Desember 2015. 2018;7(1):142-8.

6. Hunter LE, Seale AN. Educational series in congenital heart disease: Prenatal diagnosis of congenital heart disease. Echo Res Pract. 2018;5(3):R81-R100.

7. Norton M. Callen's Ultrasonography in Obstetrics and Gynecology. Philadelphia: Saunders Elsevier, 2016.

8. Hoffman JIE. The global burden of congenital heart disease. Cardiovasc J Afr. 2013;24(4):141-5.

9. Haq FU, Jalil F, Hashmi SK, Jumani MI, Imdad A, Jabeen M, Hashmi JT, Irfan A Bin, Imran M, Atiq M. Risk factors predisposing to congenital heart defects. Ann Pediatr Cardiol. 2011;4(2):117-21.

10. Abqari S, Gupta A, Shahab T, Rabbani MU, Ali SM, Firdaus U. Profile and risk factors for congenital heart defects: A study in a tertiary care hospital. Ann Pediatr Cardiol. 2016;9(3):216-21.

11. Pei L, Kang Y, Zhao Y, Yan H. Prevalence and risk factors of congenital heart defects among live births: A population-based cross-sectional survey in Shaanxi province, Northwestern China. BMC Pediatr. 2017;17(1):1-8.

12. Blue GM, Kirk EP, Sholler GF, Harvey RP, Winlaw DS. Congenital heart disease: Current knowledge about causes and inheritance. Med J Aust. 2012;197(3):155-9.

13. Van Beynum IM, Kapusta L, Den Heijer M, Vermeulen SHHM, Kouwenberg M, Daniëls O, et al. Maternal MTHFR $677 \mathrm{C}>\mathrm{T}$ is a risk factor for congenital heart defects: Effect modification by periconceptional folate supplementation. Eur Heart J. 2006;27(8):981-7.

14. Yuan Y, Yu X, Niu F, Lu N. Genetic polymorphism of methylenetetrahydrofolate reductase as a potential risk factor for congenital heart disease. Med (United States). 2017;96(23):1-8.

15. Antonaros F, Olivucci G, Cicchini E, Ramacieri 
G, Pelleri MC, Vitale L, et al. MTHFR C677T polymorphism analysis: A simple, effective restriction enzyme-based method improving previous protocols. Mol Genet Genomic Med. 2019;7(5):1-9.

16. Wang W, Wang $\mathrm{Y}$, Gong $\mathrm{F}$, Zhu W, Fu S. MTHFR C677T polymorphism and risk of congenital heart defects: Evidence from 29 case-control and TDT studies. PLoS One. 2013;8(3):1-8.

17. Liew SC, Gupta E Das. Methylenetetrahydrofolate reductase (MTHFR) C677T polymorphism: Epidemiology, metabolism and the associated diseases. Eur $\mathrm{J}$ Med Genet. 2015;58(1):1-10.

18. Xuan C, Li H, Zhao JX, Wang HW, Wang Y, Ning CP, et al. Association between MTHFR polymorphisms and congenital heart disease: A meta-analysis based on 9,329 cases and 15,076 controls. Sci Rep. 2014;4:1-13.

19. Wang W, Hou Z, Wang C, Wei C, Li Y, Jiang L. Association between 10methylenetetrahydrofolate reductase (MTHFR) polymorphisms and congenital heart disease: A meta-analysis. Meta Gene. 2013;1(245):10925.

20. Nie Y, Gu H, Gong J, Wang J, Gong D, Cong X, et al. Methylenetetrahydrofolate reductase C677T polymorphism and congenital heart disease: A meta-analysis. Clin Chem Lab Med. 2011;49(12):2101-8.

21. Moorman A, Webb S, Brown NA, Lamers W, Anderson RH. Development of the heart: Formation of the cardiac chambers and arterial trunks. Heart. 2003;89(7):806-14.

22. Sadler TW. Langman's Medical Embryology. 14th ed. Wolters Kluwers; 2019.

23. Marek J, Tomek V, Škovránek J, Povýšilová V, Šamánek M. Prenatal ultrasound screening of congenital heart disease in an unselected national population: A 21-year experience. Heart. 2011;97(2):124-30.

24. Singh Y, McGeoch L. Fetal anomaly screening for detection of congenital heart defects. J
Neonatal Biol. 2016;05(02).

25. Rocha LA, Araujo Júnior E, Rolo LC, Barros FSB, Da Silva KP, Leslie ATFS, et al. Prenatal detection of congenital heart diseases: Oneyear survey performing a screening protocol in a single reference center in Brazil. Cardiol Res Pract. 2014;2014.

26. Truong UT, Kutty S, Broberg CS, Sahn DJ. Multimodality imaging in congenital heart disease: An update. Curr Cardiovasc Imaging Rep. 2012;5(6):481-90.

27. The International Society of Ultrasound in Obstetrics. ISUOG Practice Guidelines (updated): Sonographic screening examination of the fetal heart. Ultrasound Obstet Gynecol. 2013;41(3):348-59.

28. Rajiah P, Mak C, Dubinksy TJ, Dighe M. Ultrasound of fetal cardiac anomalies. Am J Roentgenol. 2011;197(4):747-60.

29. American Institute of Ultrasound in Medicine. AIUM Practice guideline for the performance of fetal echocardiography. J Ultrasound Med. 2013;32(32):1067-82.

30. Ganapathy K, Solomo N. The basis of management of congenital heart disease. Princ Pract Cardiothorac Surg. 2013:221-71.

31. Seghaye MC. Management of children with congenital heart defect: State of the art and future prospects. Future Cardiol. 2017;13(1):65-79.

32. Puri K, Allen HD, Qureshi AM. Congenital heart disease. Pediatr Rev. 2017;38(10):47184.

33. Miyoshi T, Hosoda H, Nakai M, Nishimura K, Miyazato M, Kangawa K, et al. Maternal biomarkers for fetal heart failure in fetuses with congenital heart defects or arrhythmias. Am J Obstet Gynecol. 2019;220(1): 104.e1104.e15.

34. Biró O, Rigó J, Nagy B. Noninvasive prenatal testing for congenital heart disease-cell-free nucleic acid and protein biomarkers in maternal blood. J Matern Neonatal Med. 2020;33(6):1044-50. 
35. Panch T, Szolovits P, Atun R. Artificial intelligence, machine learning and health systems. J Glob Health. 2018;8(2):1-8.

36. Garcia-Canadilla P, Sanchez-Martinez S, Crispi F, Bijnens B. Machine learning in fetal cardiology: What to expect. Fetal Diagn Ther. 2020;47(5):363-72.

37. Pesapane F, Volonté C, Codari M, Sardanelli F. Artificial intelligence as a medical device in radiology: Ethical and regulatory issues in Europe and the United States. Insights Imaging. 2018;9(5):745-53.

38. Dzobo K, Adotey S, Thomford NE, Dzobo W. Integrating artificial and human intelligence: $\mathrm{A}$ partnership for responsible innovation in biomedical engineering and medicine. Omi A J Integr Biol. 2020;24(5):247-63.

39. Wu L, Cheng JZ, Li S, Lei B, Wang T, Ni D. FUIQA: Fetal ultrasound image quality assessment with deep convolutional networks. IEEE Trans Cybern. 2017;47(5):1336-49.

40. Yu L, Guo Y, Wang Y, Yu J, Chen P. Segmentation of fetal left ventricle in echocardiographic sequences based on dynamic convolutional neural networks. IEEE Trans Biomed Eng. 2017;64(8):1886-95.

41. Dong S, Luo G, Wang K, Cao S, Li Q, Zhang H. A combined fully convolutional networks and deformable model for automatic left ventricle segmentation based on 3D echocardiography. Biomed Res Int. 2018;1-16.

42. Bridge CP, Ioannou C, Noble JA. Automated annotation and quantitative description of ultrasound videos of the fetal heart. Med Image Anal. 2017; 36:147-61.

43. Arnaout R, Curran L, Chinn E, Zhao Y, MoonGrady A. Deep-learning models improve on community-level diagnosis for common congenital heart disease lesions. 2018; 368:117. 